\title{
Enhancing the Teaching and Learning of Computer Programming using Collaborative Method of Delivery
}

\author{
Oladimeji Adegbola Isaac ${ }^{1}$, Njoku Christian $C^{2}$ and Yusuf Hussaini Amana ${ }^{3}$ \\ Computer Science Education Department \\ School of Science \\ Aminu Saleh College of Education, \\ Azare, Bauchi State \\ Nigeria
}

\begin{abstract}
Teaching and learning methodologies in modern times are gradually changing and is no longer an art of transferring knowledge. It has become an enterprise to develop critical thinking, create positive interaction and collaboration among learners. In order to build good and successful computer programmers, the Collaborative teaching and learning method remains the best method of delivery. The population for this study consists of NCE I, II and III students from the Department of Computer Science Education of Aminu Saleh College of Education Azare, Bauchi State and 10 lecturers from the same department and school. A sample of 80 students and 10 lecturers was used for this study. A well-structured questionnaire titled "Effects of Collaborative Teaching and Learning on programming" was used to collect data for the study. The questionnaire items were validated by experts in the field of statistics and it was also tested and retested for reliability. Data collected were analyzed using mean to answer the research questions. The study revealed that there are great benefits in using the collaborative methods in teaching and learning programming. Such benefits include improvement of students' academic performance, creation of positive interaction among students, and development of critical thinking abilities among others. The study also found that there are challenges associated with collaborative learning such as the formation of groups, the challenge of monitoring the group activities at once considering the limited time for the class, etc. The study recommends the integration of collaborative learning by computer educators so as to assist students in mastering programming. It also recommends that computer educators be proactive in grouping students so as to avoid imbalance. This will encourage more enthusiastic and active involvement by the students.
\end{abstract}

Key words: Collaborative learning, Programming, Computer Science.

\section{INTRODUCTION}

Teaching and learning in recent times have changed compared to methods used in the last 20 to 25 years ago when teachers were seen to be authoritative and entertaining, his words were carefully listened to by students who obediently take notes. While this style worked for other courses in schools, it never worked for courses for computer programming. There are assorted and complex challenges in the act of teaching in various institutions in Nigeria, however, the major challenge is on the pedagogical component. To make computer programming realistic and innovative, the best methodology to deliver must be employed. Programming has been seen to be a very hard task for students because it requires high metacognitive skills like abstraction, deep comprehension and long awareness, and many steps in problem-solving from analysis to debugging and testing (Boudia, Bengueddach and Haffsaf, (2019) in Arboleda, Mazuera and Montemiranda (2015). Other difficulties emanate during laboratory sessions, such as large number of students per class. These challenges could be overcome by using collaborative learning - a method which enables students to help each other in groups to solve problems and keeping each other focused on the task, and being encouraged to articulate issues along the way.

\section{LITERATURE REVIEW}

Computer programming, which is a discipline in computer science, is the process of writing instructions (in a particular programming language) that gets executed by computers. It is a process of designing and writing an executable computer code to 
perform or accomplish a particular task (Shaun, 2014). Programming is also the act of writing computer codes or building step-bystep instructions that directs the computer to do the task one wants it to do and produce the required result.

Learning to write computer programs in school by students has never been an easy task due largely to issues like abstraction, critical thinking, analytical abilities, etc. Syntax error and lack of ability to find errors, develop a program to solve a task and modularization of code using functions and procedures have been seen as of the barriers of new programmers (Deny et al, 2011, Bosse and Gerosa, 2016).This are the reasons as noted by Oroma, Wanga and Ngumbuke (2015), also the researchers of this work who are lecturers in the department of computer science education, behind the failure rates witnessed in most schools. Proficiency in programming requires essential skills such as learning the language, composing new programs, debugging, and understanding, reusing and integrating existing programs (Isong, 2014). Therefore, the method of delivery of programming which is a key course in computer science is highly critical to understanding it.

Brown (2017) sees Collaborative learning (CL) as one of the teaching approaches where students work in groups so as to understand a concept, create a product or solve a problem. It provides a conducive environment which enlivens and enrich the learning process thereby sustaining the student's interests and provide a natural learning habit. Students are given the opportunity to learn relatively realistic, cognitively motivating and socially enriched learning contexts, compared to other tutoring models such as discovery learning, integrated learning etc. This is in contrast with individual learning, students engage with one another to ask for information, evaluate their ideas and monitor their work together. It is a type of learning which seems to be more effective when two or more learners or students learn something different together. In this learning style, students learn new things with each other's help. Collaborative learning can also be defined as an instruction method in which learners at various performance levels work together in small groups toward a common goal (Laal \& Ghodsi, 2012).

Hence, CL can be described as a pedagogical method where intellectual effort between students, or students and teachers come together towards the achievement of academic goal. Collaborative learning can take the form of face-to-face communication or use of computer platforms such as chat-room or Online forums. Collaborative writing, group projects, problem-solving, discussions, study groups etc. are the main tasks in CL (Smith and MacGregor, (1992).

A Collaborative learning environment usually gets students challenged both socially and emotionally. This is because they listen to various ideas coming from class mates and are expected to participate by giving their own ideas and to defend it. This assists the students in acquiring problem-solving skills and without depending on others.(Laal\&Laal, 2011).

The world, as we know is made up of human interaction. Though we live in a generation where digital tools, 3D printing, robotics, Internet of Things (IoT) and augmented reality is taking up a larger space everyday ( the 4th industrial revolution), human interaction will always be exceptionally important. As machines such as robots are gradually replacing humans in work places, there are also soft-skills that must be strengthened in order to succeed both now and in the near future. Some of these soft-skills are collaboration, creativity, human interaction and critical thinking. Collaborative learning approach ensures that we not only teach the necessary knowledge, but also the skill of collaboration which is becoming very imperative today (Elbelman, 2018).

The major purpose of this study is to create awareness on the effectiveness of collaborative learning especially in computer programming. The authors have carefully gone through the factors that hinder or retard the teaching and learning of computer programming in schools and have decided to bridge the gap by presenting collaborative method as the best way of teaching and learning computer programming.

\section{METHODOLOGY}

\section{Research Questions/ Objectives of the study}

This study is aim at seeking the answers to following questions,

1. Why do many students fail programming?

2. In what ways does collaborative method help teachers in teaching computer programming?

3. What are the challenges of collaborative method in tertiary institutions?

4. What makes Collaborative learning effective?

5. What are the effects of collaborative learning on students learning programming?

6. What are the impacts of collaborative learning on programming? 


\subsection{Sampling}

The population for the study consists of students of year one, two and year three levels (NCE I, II and III) and lecturers from Computer Science Education Department, Aminu Saleh College of Education, Azare, in Katagum Local Government Area of Bauchi State. A descriptive survey was designed for this study. The sample for the study is made up of 80 students (20 from NCE I, 30 each from NCE II and II) and 10 lecturers, all from the same department. The instrument used to collect data is questionnaire which was designed by the researchers. A questionnaire is a research instrument consisting sets of questions or other types of prompts that aims at collecting information from a respondent. The questionnaire was administered to the respondents after proper validation by senior research experts who constructively criticized and made valuable input to questionnaire. The items were found to be reliable after multiple tests. The valid responses collected was analyzed using a four (4) point Scale (SA=Strongly Agreed, $\mathrm{A}=$ Agree, $\mathrm{D}=$ Disagreed and SD =Strongly Disagreed) with points 4,3,2,1 assigned respectively and 2.50 and above as criteria for acceptance and less for rejection. To get the mean score for each item, the frequency of each level on the scale was first determined and multiplied by the point allocated to the level to get the weighted score. This was then divided by the number of respondents to get the mean score.

\section{IV.RESULTS AND DISCUSSION}

Results of the study are presented below:

Section 1: Lecturers Responses

Table 1: Why do many students fail programming?

\begin{tabular}{|l|l|l|l|l|l|l|}
\hline S/N & \multicolumn{1}{|c|}{ ITEM SA } & A & D & SD & $\overline{\mathbf{x}}$ \\
\hline 1 & $\begin{array}{l}\text { It is hard to understand the purpose of programs and their } \\
\text { relationship with the computer }\end{array}$ & 4 & 3 & 2 & 1 & 3.0 \\
\hline 2 & $\begin{array}{l}\text { It is tough understanding the syntax and semantics of particular } \\
\text { programming language }\end{array}$ & 5 & 4 & 1 & 0 & 3.4 \\
\hline 3 & \begin{tabular}{l} 
There is the problem of inadequate knowledge of problem solving \\
\hline 4
\end{tabular} & 4 & 6 & 0 & 0 & 3.4 \\
\hline 5 & $\begin{array}{l}\text { No programming experience or background fopropriate teaching methods causes high failure rates in } \\
\text { programming and data structures }\end{array}$ & 3 & 4 & 1 & 2 & 2.8 \\
\hline
\end{tabular}

The table shows that one of the reasons why students of Computer Science Education of Aminu Saleh College of Education, Azare fail programming and data structures and algorithm is because they find it difficult to understand the purpose of programs and their relationship with the computer. This is made known by the mean of 3.0. They also believe that it is tough understanding the syntax and semantics of particular programming language (3.4). They also accepted that they do not have adequate knowledge of problem solving techniques (3.4). The table also reveals that most of the students does not have programming experience (3.1). Another reason for high failure rate is inappropriate teaching methods (2.8).

Table 2: In what ways does collaborative method help teachers in teaching computer programming?

\begin{tabular}{|l|l|l|l|l|l|l|}
\hline $\mathbf{S} / \mathbf{N}$ & \multicolumn{1}{|c|}{ ITEM } & \multicolumn{1}{|c|}{ SA } & \multicolumn{1}{|c|}{ - D } & \multicolumn{1}{|c|}{ SD } & \multicolumn{1}{|c|}{} \\
\hline 1 & $\begin{array}{l}\text { It helps teachers to spend less time in class explaining } \\
\text { concepts }\end{array}$ & 4 & 3 & 1 & 2 & 2.9 \\
\hline 2 & It helps to measure how well students are doing & 5 & 3 & 2 & 1 & 3.4 \\
\hline 3 & $\begin{array}{l}\text { Collaborative teaching and learning creates the desire for } \\
\text { students to come to class }\end{array}$ & 3 & 3 & 3 & 1 & 2.8 \\
\hline 4 & It gives more time for the students to practice & 4 & 4 & 1 & 1 & 3.5 \\
\hline 5 & It makes the students to be more productive & 5 & 3 & 0 & 2 & 3.1 \\
\hline
\end{tabular}

From the table, collaborative method helps teachers to spend less time in class, as indicated by the mean of 2.9. The lecturers said that the method assists them in measuring how well the students are doing (3.4). The lecturers also said that collaborative method creates the desire for students to come to class (2.8). Collaborative method gives the students more time for practice (3.5) and makes the students to be more productive (3.1). 
International Journal of Advances in Scientific Research and Engineering (ijasre), Vol 7 (1), January -2021

Table 3: What are the challenges of collaborative method in tertiary institutions?

\begin{tabular}{|c|c|c|c|c|c|c|}
\hline $\mathbf{S} / \mathbf{N}$ & ITEM & SA & A & $\mathbf{D}$ & SD & $\overline{\mathbf{x}}$ \\
\hline 1 & $\begin{array}{l}\text { Student-computer ratio is a major challenge in learning } \\
\text { programming }\end{array}$ & 5 & 3 & 1 & 1 & 3.2 \\
\hline 2 & $\begin{array}{l}\text { Monitoring group discussion/activities and intervening when } \\
\text { necessary }\end{array}$ & 4 & 4 & 4 & 0 & 3.6 \\
\hline 3 & Unequal individual participation (free-riding) & 3 & 4 & 1 & 2 & 2.9 \\
\hline 4 & Composing groups (putting brighter students in group) & 4 & 3 & 2 & 1 & 3.0 \\
\hline 5 & $\begin{array}{l}\text { Communication problems due to some students lack of } \\
\text { collaborative skills. }\end{array}$ & 3 & 3 & 2 & 2 & 2.7 \\
\hline
\end{tabular}

Table 3 shows that some of the challenges of collaborative method in Aminu Saleh College of Education are that studentcomputer ratio is a major challenge to teaching and learning of computer programming (3.2), monitoring groups activities (3.6). Another challenge is in the composition of the groups, there is the tendency of putting bright students in one group (3.0). Also some of the students finds it difficult to communicate due to lack of collaborative skills (2.7)

\section{Section2: Students Responses}

Table 1: What makes Collaborative learning effective?

\begin{tabular}{|l|l|l|l|l|l|l|}
\hline S/N & \multicolumn{1}{|c|}{ ITEM } & SA & \multicolumn{1}{|c|}{ A } & \multicolumn{1}{|c|}{ D } & \multicolumn{1}{|c|}{ SD } & $\overline{\mathbf{x}}$ \\
\hline 1 & It gives room for positive interdependence & 55 & 15 & 6 & 4 & 3.5 \\
\hline 2 & It makes provision for individual accountability & 60 & 10 & 4 & 6 & 3.6 \\
\hline 3 & It involves the efforts of every member of the group & 45 & 15 & 15 & 5 & 3.3 \\
\hline 4 & A size of 3 to 5 students makes it effective & 50 & 25 & 5 & 0 & 3.6 \\
\hline 5 & It gives room for positive interaction & 47 & 13 & 10 & 10 & 3.2 \\
\hline
\end{tabular}

Table 1 reveals that Collaborative learning gives room for positive interdependence as the mean of 3.5 shows. It also creates opportunity for individual accountability (3.6). The table further revealed that collaborative learning involves the efforts of every group member (3.3). In addition, it shows that a manageable size of 3 to 5 members in a group makes collaborative learning effective (3.6). Finally, the students agreed that collaborative learning makes provision for positive interaction (3.2).

Table 2: What are the effects of collaborative learning on students learning programming?

\begin{tabular}{|c|c|c|c|c|c|c|}
\hline $\mathbf{S} / \mathbf{N}$ & ITEM & SA & $\overline{\mathbf{A}}$ & D & SD & $\overline{\mathrm{x}}$ \\
\hline 1 & $\begin{array}{l}\text { Collaborative learning helps us to enjoy the learning } \\
\text { experience }\end{array}$ & 50 & 15 & 10 & 5 & 3.4 \\
\hline 2 & We feel motivated & 58 & 12 & 4 & 6 & 3.5 \\
\hline 3 & $\begin{array}{l}\text { It affords us the opportunity to discuss programming ideas } \\
\text { especially when giving assignment }\end{array}$ & 45 & 20 & 9 & 6 & 3.3 \\
\hline 4 & $\begin{array}{l}\text { It improves our academic performance in programming and } \\
\text { data structures }\end{array}$ & 60 & 10 & 8 & 2 & 3.6 \\
\hline 5 & $\begin{array}{l}\text { Collaborative learning helps us to do our laboratory } \\
\text { assignments on time }\end{array}$ & 48 & 12 & 18 & 2 & 3.3 \\
\hline
\end{tabular}

Table 2 shows the effects of collaborative learning on the student's computer science education department of Aminu Saleh College of Education, Azare. The students agreed that collaborative learning helps them enjoy their learning experience (3.4) they also said that it gives them the opportunity to discuss programming ideas during assignments (3.3). The students said that collaborative learning helped their academic performance on Programming and Data Structures to improve (3.6). Finally, they said that collaborative learning helps them to do their assignments on time (3.3). 
Table 3: What are the impacts of collaborative learning on programming?

\begin{tabular}{|l|l|l|l|l|l|l|}
\hline S/N & \multicolumn{1}{|c|}{ ITEM SA } & A & D & SD & $\overline{\mathbf{x}}$ \\
\hline 1 & $\begin{array}{l}\text { Collaborative learning brings about critical thinking which } \\
\text { programming language and Data Structures requires }\end{array}$ & 49 & 20 & 8 & 3 & 3.4 \\
\hline 2 & Collaborative learning fosters team work & 56 & 15 & 5 & 4 & 3.5 \\
\hline 3 & Collaborative learning improves students grades on programming & 40 & 14 & 20 & 6 & 3.1 \\
\hline 4 & It makes teaching and learning of computer programming efficient. & 50 & 10 & 15 & 5 & 3.3 \\
\hline 5 & It makes programming less difficult & 54 & 14 & 8 & 4 & 3.5 \\
\hline
\end{tabular}

Table 3 reveals that collaborative method brings about critical thinking which is key for successful learning of programming and Data Structures (3.4). The students also agreed that collaborative learning fosters team work (3.5) and improves their grades in programming (3.1). The students said that collaborative learning makes the teaching and learning of Programming and Data Structures efficient (3.3) and makes the two courses less difficult (3.5).

This study is on the impacts of collaborative method of teaching and learning of computer programming in Aminu Saleh College of Education, Azare. This study is aimed to establish the effect of collaborative learning has on academic performance especially in computer programming. The outcome reveals some interesting findings, which gives important insight into the advantages and disadvantages of collaborative learning method in the teaching and learning of computer programming. Some of the advantages as revealed in the study are: making programming less difficult, efficient, improvement in grades, and develops critical thinking in the students. While there is significant improvement in students' performance when compared to individual programming, there are still some challenges attached to the use of collaborative learning. Such challenges include: monitoring students discussion/activities, student-computer ratio, unequal individual participation, differences in ability - where students with high abilities solve almost all the problems without much contribution from those with lesser abilities etc. Collaborative learning is highly effective in teaching and learning of computer programming going by the responses of the respondents.

\section{CONCLUSION}

This research is evidence that collaborative method of instruction could serve as an effective teaching and learning strategy for mastering Programming courses in tertiary institutions. This claim has been supported not only by the literatures reviewed on collaborative teaching and learning but also by the research carried out. This work looks into the effectiveness of collaborative method of teaching and learning from both the teachers' and students' point of view so as to understand better the usefulness of the method. Though collaborative learning is not so prevalent in higher institutions, it assists in meeting so many teaching and learning objectives when properly planned. Collaborative learning helps learners to be actively involved in their courses of study especially technical courses like programming which involves a lot of thinking. Good computer programs needs team work, social cohesion and cooperation. Since it is the responsibility of the teacher to impact knowledge to the students, appropriate method of instruction such as collaborative learning should be employed for optimum result.

\section{RECOMMENDATIONS}

Based on the outcome of the research, the following recommendations are made:

1). There is need for computer educators to integrate collaborative method of teaching so as to assist the students master the art of programming which is key to computer science.

2). Student-teachers should be equipped with the strategy to understand how to support collaborative skills development for their future students.

3). Adequate care must be taken by computer educators while forming groups for collaborative learning. This is to avoid placing students of high abilities in one group, rather they should be mixed with those of low abilities.

4). Institutions of higher learning must make adequate provision for computer systems to solve the problem of studentscomputer ratio. This will encourage more enthusiastic and active involvement by the students.

5). the academic calendar should be structured in such a way that it would accommodate collaborative method of teaching and learning.

\section{REFERENCES}

[1]. Bosse, Y. \& Gerosa, M.A. (2016). Why is programming so difficult to learn? Patterns of Difficulties Related to Programming Learning. ACM SIGSOFT Software Engineering Notes. 41(6) 2

[2]. Boudia, C., Bengueddach, A. \&Haffsaf, H.(2019). Collaborative Strategy for Teaching and Learning Object-Oriented Programming Course: A Case Study of Mostafa Stambouli Mascara University, Algeria. Informatica, 43. $129-144$. 
[3]. Brown, E. (2017). Benefits of collaborative teaching and learning for students. Retrieved from https://www.eztalks.com/online-education/advantages-of-collaborative-learning.html on 12/09/2019.

[4]. Bruce, C. \& McMahon, C. (2002). Contemporary Developments in Teaching and Learning Introductory Programming: Teaching and Learning Report, Faculty of Information Technology, Queensland University of Technology, Brisbane, Australia. QUT publications and Printing.

[5]. Clarke, B. (2018). How collaborative learning enhances computing (sponsored). Retrieved from https://www.tes.com/news/how-collaborative-learning-enhances-computing-sponsored on 12/09/2019.

[6]. Denny, P. et al, (2011). Understanding the syntax barrier for novices. Proceedings of the $16^{\text {th }}$ ACM conference on Innovation and technology in computer science education.

[7]. Elbelman, A.R. (2018). Collaborative Learning: Why Coding Is The Best Field For Kids To Learn From Each Other. Retrieved from https://tekkieuni.com/blog/collaborative-code-learning/ on 10/09/2019.

[8]. Laal, M.,\&Laal, M. (2011). Collaborative Learning: What is it? Procedia - Social and Behavioral Sciences,31, 491 495.

[9]. Le, H.,Janssen, J., \&Wubbels,T. (2018). Collaborative Learning Practices: Teacher and Student perceived obstacles to effective collaboration. Cambridge Journal of Education, 48:1.

[10]. Maguire, P., Maguire, R., Hyland, P., \&Marshall, P. (2014). Enhancing Collaborative Learning Using Pair Programming: Who Benefits? All Ireland Journal of Teaching and Learning in Higher Education (AISHE-J) 6(2).Pp 5-8.

[11]. Mentz, E. , Vander Walt, J.L. \& Goosen, L. (2008). The effect of incorporating

[12]. cooperative learning principles in pair programming for student teachers, Computer Science Education, 18:4, 247-260

[13]. Oroma, J.O.,Wanga, H.,\& Ngumbuke, F.(2012). Challenges of teaching and learning computer programming in developing countries: Lessons from Tumanini University. Proceedings of INTED2012 Conference. 5th-7th March , Valencia, Spain.

[14]. Pantiz, T. (1999) in Laal, M. \&Ghodsi, S.M.(2012). Benefits of collaborative learning. Procedia - Social and Behavioral Sciences 31 (2012) 486 - 490

[15]. Scarger, K. ,Boonstra, J., Peeters,T., Vulperhorst, J., \&Wiegant, F. (2016). Collaborative Learning in Higher Education: Evoking Positive Interdependence. CBE-Life Sciences Education. 15ar69.

[16]. Shaun, B. (2014). What is coding?.Tumblr, Archived from the original on 2020-04-29.

[17]. Smith, B.L, \& MacGregor, J.(1992). Collaborative Learning: A Sourcebook for Higher Education. University Park, P.A: National Center on Postsecondary Teaching, Learning, and Assessment (NCTLA). 9-22.

[18]. Teague, D. \& Roe, P. (2007). Learning to Program: Going Pair-Shaped. Innovation in Teaching and Learning in Information and Computer Sciences. 6(4). P.10

[19]. Tucker, Allen, (editor), Deek, F., Jones, J., McCowan, D., Stephenson, C., \&Verno, A. ,A Model Curriculum for K-12 Computer Science: Final Report of the ACM K-12 Task Force Curriculum Committee.

[20]. Wittrock, M.C. (1990). Generative processes of comprehension. EducPsychol 24, 345-376 